\title{
Utilization of oleo-chemical industry by-products for biosurfactant production
}

\author{
Garima Bhardwaj ${ }^{1}$, Swaranjit Singh Cameotra ${ }^{2}$ and Harish Kumar Chopra ${ }^{1 *}$
}

\begin{abstract}
Biosurfactants are the surface active compounds produced by micro-organisms. The eco-friendly and biodegradable nature of biosurfactants makes their usage more advantageous over chemical surfactants. Biosurfactants encompass the properties of dropping surface tension, stabilizing emulsions, promoting foaming and are usually non- toxic and biodegradable. Biosurfactants offer advantages over their synthetic counterparts in many applications ranging from environmental, food, and biomedical, cosmetic and pharmaceutical industries. The important environmental applications of biosurfactants include bioremediation and dispersion of oil spills, enhanced oil recovery and transfer of crude oil. The emphasis of present review shall be with reference to the commercial production, current developments and future perspectives of a variety of approaches of biosurfactant production from the micro-organisms isolated from various oil- contaminated sites and from the by-products of oleo-chemical industry wastes/ by-products viz. used edible oil, industrial residues, acid oil, deodorizer distillate, soap-stock etc.
\end{abstract}

Keywords: Biosurfactants; Agro- chemical waste; Rhamnolipid; Oil industry

\section{Introduction}

Biosurfactants are the surface active agents that are amphipathic in nature and possess both hydrophilic and hydrophobic moieties that reduce the surface and interfacial tensions between two immiscible liquids. The polar and non-polar moieties present in the structure of biosurfactants allow them to accumulate at inter-phase between liquids of different polarities and form micelles thereby reducing surface tension and facilitating hydrocarbon uptake and emulsification. The interest in biosurfactants is taking much more attention these days due to their promising quality towards the environment. The biosurfactants are preferred over their chemically synthesised counterparts because of their higher biodegradability and selective nature towards the environmental factors like temperature, $\mathrm{pH}$, and salinity. However, the biosurfactants are not able to compete with the chemical surfactants due to their higher production costs (Gautam and Tyagi 2006; Pacwa-Plociniczak et al. 2011). Their future completely depends upon the economic balance between their production costs, functional

\footnotetext{
* Correspondence: hk67@rediffmail.com

'Department of Chemistry, Sant Longowal Institute of Engineering and

Technology, Longowal, 148106, Distt. Sangrur (Pb.), India

Full list of author information is available at the end of the article
}

benefits and the development of economical processes by the use of low cost raw materials (Cameotra and Makkar 1998; Desai and Banat 1997). Therefore a lot of wastes are getting attention in response to reduce the cost of biosurfactant production and their use world-wide for a better environment. Some of these wastes include vegetable oils, distillery and dairy wastes which can be used efficiently to reduce the biosurfactant production costs (Makkar and Cameotra 2002). Oil industry waste in the form of byproducts generated during the manufacture of vegetable oil is found to be very useful. Therefore our main purpose is to consider various oil industry wastes for the production of biosurfactants as efficient and economical raw materials in order to lower the cost of biosurfactant production.

The process of biosurfactant production can be optimized by making the possible links between the production conditions, structure and function of these compounds (Makkar et al. 2011). Biosurfactants are widely used in hydrocarbon bioremediation field due to their enhanced oil recovery (EOR). Their presence lowers the surface and interfacial tension of the oil reservoirs which facilitate the oil flow and thus enhance the oil recovery (Kosaric 1992). Besides their use in enhanced oil recovery soil remediation is also of great 
importance where they accelerate the remediation of organic and metal contaminated sites (Christofi and Ivshina 2002). Other potential applications of biosurfactants relate to food, cosmetic, health care industries and cleaning toxic chemicals of industrial, agricultural origin and industrial waste utilization. The chemical structures of some of the common biosurfactants isolated from oleo-chemical industry waste are shown in Figure 1.

\section{Micro-organisms producing biosurfactants}

A variety of micro-organisms produce biosurfactants that are diverse in chemical composition. The nature and amount of the biosurfactant produced solely depends upon the site from where the micro-organism is isolated and the various nutritional factors available for their growth (Table 1). Many microorganisms have been isolated from contaminated soils, effluents and waste water sources for industrial utilization of the various types of agro-industrial waste products. Thus, these have an ability to grow on substrates considered potentially noxious for other non-producing microorganisms.

\section{Maximum production and recovery of biosurfactants via microbial bioprocess development}

The bio-process optimization is a very important aspect of biosurfactant production using various industrial wastes. Several factors need to be considered before a standard procedure is laid out for the setting up the process at industrial level. These are described as follows.

\section{Factors affecting the biosurfactant production}

Many factors affect the production of biosurfactants at the genetic, nutritional and physicochemical environment levels. Several carbon and nitrogen sources which helps in the growth of micro-organisms but they are not suitable for the production of biosurfactants. Some of the carbon-nitrogen sources and the environmental factors affecting the production of biosurfactants selected from oil industry are discussed here.

\section{Carbon sources}

In case of hydrophilic substrates Pichia anamola supported better growth in glucose and in case of hydrophobic substrates soyabean and palm oil were the best carbon sources as compared to coconut oil as a very low amount of biosurfactant is produced on it. The surface tension reduced to $28 \mathrm{mN} / \mathrm{m}$ suggesting the secretion of biosurfactants in the fermentation media (Thaniyavarn et al. 2008). When grown on used edible oil as a carbon source Pseudomonas $s p$ was able to produce maximum yield of biosurfactant which was $7.6 \mathrm{~g} / \mathrm{L}$ compared to rice water, diesel, petrol and whey (Soniyamby et al. 2011). Olive oil was the best carbon source for the production of biosurfactants by Pseudomonas fluorescence compared to the hexadecane and glucose which reduced the surface tension of the fermentation media to 38 dyne/cm and an emulsification activity of $49 \%$. Hexadecane was also able to reduce the surface tension of the fermentation media but with only $10 \%$ emulsification activity while on glucose the strain grew without biosurfactant production (Abouseoud et al. 2007).

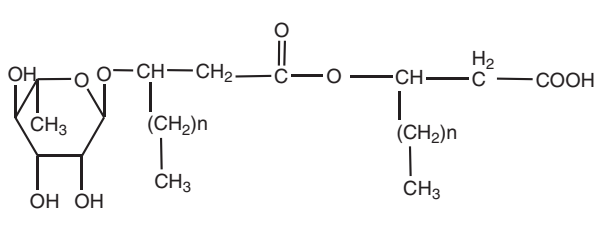

Monorhamnolipid

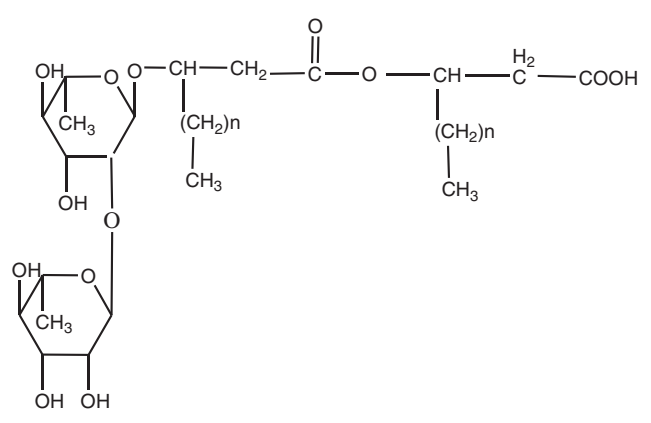

Dirhamnolipid

Figure 1 Various types of biosurfactants produced by microorganisms.
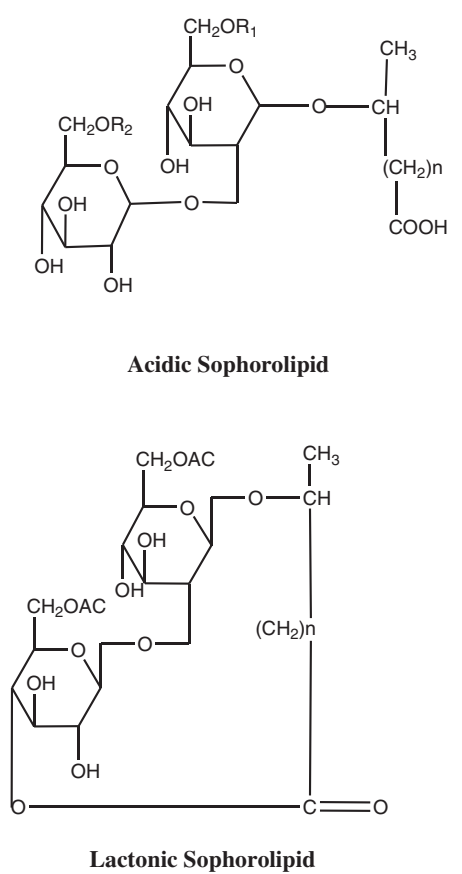
Table 1 Potential biosurfactants with their producing micro-organisms

\begin{tabular}{|c|c|c|c|c|}
\hline Microorganism & Sources of isolation & By-products/ Carbon Sources & Biosurfactant & Reference \\
\hline Pseudomonas sp. & Oil spilled soil & Glucose/ Molasses/ Cheese whey & Rhamnolipid & $\begin{array}{l}\text { Anandaraj and } \\
\text { Thivakaran } 2010\end{array}$ \\
\hline Pseudomonas sp. & Used edible oil & $\begin{array}{l}\text { Used edible oil/ Rice-water/ Diesel/ } \\
\text { Petrol/ Whey }\end{array}$ & Rhamnolipid & Soniyamby et al. 2011 \\
\hline Bacillus subtilis & $\begin{array}{l}\text { Crude oil contaminated } \\
\text { localities }\end{array}$ & $\begin{array}{l}\text { Glucose/ Rapeseed oil supplemented } \\
\text { with crude oil }\end{array}$ & Iturin & Bayoumi et al. 2010 \\
\hline Bordetella hinizi-DAFI & $\begin{array}{l}\text { Crude oil contaminated } \\
\text { localities }\end{array}$ & $\begin{array}{l}\text { Sucrose/ Molasses supplemented } \\
\text { with crude oil }\end{array}$ & $\begin{array}{l}\text { Trehalose-2,3,4,2'- } \\
\text { tetraester }\end{array}$ & Bayoumi et al. 2010 \\
\hline Trichosporon asahii & $\begin{array}{l}\text { Petroleum-contaminated } \\
\text { soil }\end{array}$ & Diesel oil & Sophorolipids & 2010 \\
\hline $\begin{array}{l}\text { Pseudomonas } \\
\text { aeruginosa } L B I\end{array}$ & $\begin{array}{l}\text { Petroleum contaminated } \\
\text { soil }\end{array}$ & Soap-stock & Rhamnolipids & Benincasa et al. 2002 \\
\hline Serratia marcescens & $\begin{array}{l}\text { Petroleum contaminated } \\
\text { soil }\end{array}$ & Glycerol & Lipopeptide & Anyanwu et al. 2011 \\
\hline Candida sp. SY-16 & Oil-containing soil sample & Soybean oil and glucose & $\begin{array}{l}\text { Mannosylerythritol } \\
\text { (Glycolipid) }\end{array}$ & Kim et al. 1999 \\
\hline $\begin{array}{l}\text { Pseudomonas } \\
\text { aeruginosa SP4 }\end{array}$ & $\begin{array}{l}\text { Petroleum contaminated } \\
\text { soil }\end{array}$ & Palm oil & Rhamnolipid & Sarachat et al. 2010 \\
\hline Rhodococcus sp. & Oil-contaminated soil & $\begin{array}{l}\text { Sucrose/ Kerosene/ n-heptane/ n-octane/ } \\
\text { n-hexadecane/ n-paraffin/gas oil }\end{array}$ & $\begin{array}{l}\text { Extra-cellular lipids } \\
\text { and glycolipid }\end{array}$ & Shavandi et al. 2011 \\
\hline Bacillus subtilis & Oil contaminated soil & Vegetable oil/ Kerosene/ Petrol/ Diesel & Surfactin & Priya et al. 2009 \\
\hline $\begin{array}{l}\text { Pseudomonas } \\
\text { aeruginosa }\end{array}$ & Oil contaminated soil & Vegetable oil/ Kerosene/ Petrol/ Diesel & Rhamnolipid & Priya et al. 2009 \\
\hline $\begin{array}{l}\text { Pseudomonas } \\
\text { aeruginosa J4 }\end{array}$ & $\begin{array}{l}\text { Waste water of } \\
\text { petrochemical factory }\end{array}$ & $\begin{array}{l}\text { Glucose/ Diesel, Kerosene/Glycerol/ Olive Oil/ } \\
\text { Sunflower oil/ Grape seed oil }\end{array}$ & Rhamnolipid & Wei et al. 2005 \\
\hline $\begin{array}{l}\text { Pseudomonas } \\
\text { aeruginosa EM1 }\end{array}$ & Oil contaminated site & $\begin{array}{l}\text { Glucose/ Glycerol/ Sucrose/ Hexane/ Olive oil/ } \\
\text { Oleic acid/ soybean oil }\end{array}$ & Rhamnolipid & Wu et al. 2008 \\
\hline
\end{tabular}

Soybean oil and glucose were used as the carbon sources for the production of mannosylerythritol lipid from Candida sp. SY 16 which lowered the surface tension to 29 dyne/cm at critical micelle concentration of $10 \mathrm{mg} / \mathrm{l}$ (Kim et al. 1999). Biosurfactants produced from the Industrial residue by Candida lipolytica are very promising to their use in microbial enhanced oil recovery due to their high tolerance to $\mathrm{NaCl}$ concentrations which is mainly found in various oil reservoirs (Rufino et al. 2007). The optimized conditions for the production of biosurfactants from the Pseudomonas aeruginosa SCMU106 included a combination of glucose and corn oil (Techaoei et al. 2011). $4 \%$ soybean cooking oil was used as a carbon source for the production of monoacylglycerols by Candida ishiwadae strain isolated from plant material (Thanomsub et al. 2004). $2 \%$ of palm oil was used to obtain the highest concentrations of biosurfactants by Pseudomonas aeruginosa SP4 strain isolated from petroleum contaminated soil (Sarachat et al. 2010). When sunflower oil was used as the carbon source by Tsukamurella spec. DSM 44370 a mixture of oligosaccharide lipids were produced. In case the carbon source was replaced with calendula oil the nature of the biosurfactant changed (Langer et al. 2006).
Biosurfactant production was enhanced during growth of Nocardiopsis sp. B4 when olive oil was used as the carbon source (Khopade et al. 2012). Three soybean oil refinement wastes; acid oil, deodorizer distillate and soapstock were used by the Pseudomonas aeruginosa MR01 as carbon sources to reduce the cost of biosurfactant production (Partovi et al. 2013). The use of soap-stock as the sole carbon source by Pseudomonas aeruginosa LBI resulted in the production of $16 \mathrm{~g} / \mathrm{L}$ of the rhamnolipids (Benincasa et al. 2002). A strain Pseudomonas aeruginosa $\mathrm{J} 4$ isolated from the waste water of petrochemical industry was able to degrade the vegetable oil as well as mineral oil for the production of biosurfactants. The maximum production of biosurfactants was $3600 \mathrm{mg} / \mathrm{L}$ which was achieved with the $10 \%$ olive oil concentration (Wei et al. 2005).

\section{Nitrogen sources}

Yeast extract was the best nitrogen source used for the production of biosurfactant by Bacillus strains isolated from the marine sediments of Tamil Nadu coastal area. Also, the beef extract showed no significant change in biosurfactant production while used in place of yeast 
extract (Gnanamani et al. 2010). Pseudomonas sp showed the better yields of biosurfactant when grown on sodium nitrate as compared to the ammonia and urea (Soniyamby et al. 2011). Pseudomonas fluorescence growing on olive oil as the carbon source found to be more efficient biosurfactant producer with ammonium nitrate as the nitrogen source as compared to the sodium nitrate and ammonium chloride. Ammonium chloride was used for the growth but not for the biosurfactant production (Abouseoud et al. 2007). Peptone was found to be an essential component for the production of biosurfactants by Lactobacillus paracasei ssp. Paracasei A20 while yeast extract was a promising component for the growth of bacteria. A combination of the peptone and meat extract showed an increase in the yield of biosurfactant compared to the standard media (Gudina et al. 2011). Phenylalanine was the most efficient nitrogen source for the cultivation of Nocardiopsis sp. B4 when used in combination with the olive oil as the carbon source (Khopade et al. 2012). The strain Pseudomonas aeruginosa EM1 isolated from the oil contaminated sites was screened for the use of various nitrogen sources to give the maximum production of biosurfactants and $\mathrm{NaNO}_{3}$ was found to be the best among $\mathrm{NH}_{4} \mathrm{NO}_{3}, \mathrm{NH}_{4} \mathrm{Cl}$, urea and yeast extract (Wu et al. 2008).

\section{Environmental factors affecting the production of biosurfactants}

Growth conditions and environmental factors such as temperature, $\mathrm{pH}$, salinity, agitation and oxygen availability also affect the production of biosurfactants. A lipopeptide biosurfactant produced by Serratia marcescens was able to retain its properties at high temperatures range up to $100^{\circ} \mathrm{C}$, high $\mathrm{NaCl}$ concentrations up to $12 \%$ and a wide range of $\mathrm{pH}$ (Anyanwu et al. 2011). The optimum temperature and $\mathrm{pH}$ for the Bacillus strains isolated from the marine sediments of Tamil Nadu coastal area were $37^{\circ} \mathrm{C}$ and $7.2 \pm 0.2$ respectively (Gnanamani et al. 2010). The incubation time plays a significant role in the production of biosurfactants. The effect of incubation time can be seen by monitoring the values of emulsification activity, surface tension, biomass concentration after a regular interval of time. Pseudomonas $s p$ showed the maximum rhamnolipid production of $5.86 \mathrm{~g} / \mathrm{L}$ at $72 \mathrm{~h}$ (Soniyamby et al. 2011). Pseudomonas fluorescence after $36 \mathrm{~h}$ of incubation starts producing biosurfactant and reaches to its maximum concentration after about $56 \mathrm{~h}$ (Abouseoud et al. 2007). The product yield increased to $70 \%$ when aeration is supplied to the Pseudomonas aeruginosa LBI in a batch feed culture (Benincasa et al. 2002). In the batch fermentation of Pseudomonas aeruginosa EM1 when the agitation was increased from 50 to $250 \mathrm{rpm}$ the rhamnolipid production increased to $80 \%$ (Wei et al. 2005).

\section{Applications}

The biosurfactants possess a lot of applications ranging from environmental, food and biomedical, cosmetic and pharmaceutical industries. Some of the reported oil related applications are discussed here. The biosurfactants isolated from Candida lipolytica, Candida antarctica, Candida bombicola, Torulopsis bombicola and Aspergillus ustus were found to be the best choices in microbial enhanced oil recovery (Rufino et al. 2007; Kitamoto et al. 2001; Adamczak and Bednarski 2000; Felse et al. 2007; Cooper and Paddock 1984; Seghal Kiran et al. 2009). The biosurfactant produced by Lactobacillus delbrueckii when grown on peanut oil was used in the bioremediation processes and helped in biodegradation of crude oil in laboratory scale microcosm experiments (Thavasi et al. 2011). Rhodococcus sp. isolated from the Iranian oil contaminated soil was able to recover $65 \%$ of the trapped oil in a sand pack column which suggests its applications in the enhanced oil recovery (Shavandi et al. 2011). The biosurfactant produced from Serratia marcescens NSK1 was able to remove $60 \%$ of the engine oil and $51 \%$ of kerosene in a soil column study which suggest its various applications in microbial enhanced oil recovery (Anyanwu et al. 2011). The modified biosurfactant of Tsukamurella sp showed novel biological activities (Langer et al. 2006). Glycolipids from Ustilago maydis FBD 12 showed significant antimicrobial activities against Salmonella enteric Var. Typhimurium and Staphyloccocus aureus (Alejandro et al. 2011). The biosurfactant from the strain Pseudomonas aeruginosa EM1 isolated from the waste water of petrochemical industry was stated to be a good one to be used in the biodegradation processes (Wei et al. 2005). These all properties show their potential of usage at industrial level for a greener environment.

\section{Conclusions}

This present review provides the basic scientific information on the production and applications of biosurfactants from the oleo-chemical industrial wastes that is required to exploit natural processes and develop methods to hasten these processes for economically viable production of biosurfactants by the usage of oil industry wastes. Regardless of the advantages of biosurfactant synthesis, its industrial use is still limited due to the high costs involved in the production process. The economics of biosurfactant production may be significantly impacted through the use of inexpensive carbon substrates. In this review, we have presented a thorough investigation of oleo chemical industry waste as carbon sources for biosurfactant production. Rapid advances in the last few years helped in the understanding of the process of biosurfactant fermentation/ production by many microorganisms. 


\section{Future prospects}

The biodegradable and low toxicity of biosurfactants makes them very promising for use in environmental sciences. The commercial success of biosurfactants is still limited owing to their high production costs. Optimized growth conditions using inexpensive renewable wastes and novel, efficient methods for isolation and purification of biosurfactants could make their production more economically feasible. Another important aspect regarding biological remediation technologies is the use of biosurfactant in the process on a large scale.

\section{Competing interests}

The authors declare that they have no competing interest.

\section{Authors' contributions}

All authors read and approved the final version of the manuscript.

\section{Author details}

'Department of Chemistry, Sant Longowal Institute of Engineering and Technology, Longowal, 148106, Distt. Sangrur (Pb.), India. ${ }^{2}$ Institute of Microbial Technology, Sector-39-A, Chandigarh 160036, India.

Received: 16 October 2013 Accepted: 21 October 2013

Published: 21 November 2013

\section{References}

Abouseoud M, Maachi R, Amrane A (2007) Biosurfactant Production from Olive Oil by Pseudomonas fluorescence. In: Mendez-Vilas A (ed) Communicating Current Research and Educational Topics and Trends in Appl Microbiol., pp 340-347

Adamczak M, Bednarski W (2000) Influence of medium composition and aeration on the synthesis of biosurfactants produced by Candida antarctica. Biotechnol Lett 22:313-316

Alejandro CS, Humberto HS, Maris JF (2011) Production of glycolipids with antimicrobial activity by Ustilago maydis FBD 12 in submerged culture. Afr J Microbiol Res 5:2512-2523

Anandaraj B, Thivakaran P (2010) Isolation and production of biosurfactant producing organism from oil spilled soil. J Biosci Tech 1:120-126

Anyanwu CU, Obi SKC, Okolo BN (2011) Lipopeptide biosurfactant production by Serratia marcescens NSK-1 strain isolated petroleum-contaminated soil. J Appl Sci Res 7:79-87

Bayoumi RA, Haroun BM, Ghazal EA, Maher YA (2010) Structural analysis and characteristics of biosurfactants produced by some crude oil utilizing bacterial strains. Aust J Basic Appl Sci 4:3484-3498

Benincasa M (2002) Rhamnolipid production by P. aeruginosa LBI growing on soap-stock as the sole carbon source. J Food Eng 54:283-288

Cameotra SS, Makkar RS (1998) Synthesis of biosurfactants in extreme conditions. Appl Microbiol Biotechnol 50:520-529

Chandran P, Das N (2010) Biosurfactant production and diesel oil degradation by yeast species Trichosporon asahii isolated from petroleum hydrocarbon contaminated soil. Int J Eng Sci Technol 2:6942-6953

Christofi N, Ivshina IB (2002) Microbial surfactants and their use in field studies of soil remediation. J Appl Microbiol 93:915-929

Cooper DG, Paddock DA (1984) Production of biosurfactant from Torulopsis bombicola. Appl Environ Microbiol 47:173-176

Desai JD, Banat IM (1997) Microbial production of biosurfactants and their commercial potentials. Microbiol Mol Biol Rev 61:47-64

Felse PA, Shah V, Chan J, Rao KJ, Gross RA (2007) Sophorolipid biosynthesis by Candida bombicola from industrial fatty acid residues. Enzyme Microb Technol 40:316-323

Gautam KK, Tyagi VK (2006) Microbial surfactants: a review. J Oleo Sci 55:155-166

Gnanamani A, Kavitha V, Radhakrishnan N, Mandal AB (2010) Bioremediation of crude oil contamination using microbial surface active agents: isolation, production and characterization. J Bioremed Biodegrad 1:1-8

Gudina EJ, Teixeira JA, Rodrigues LR (2011) Biosurfactant-producing Lactobacilli: Screening, Production Profiles, and effect of medium composition. Appl Environ Soil Sci 2011:1-9
Khopade A, Biao R, Liu X, Mahadik K, Zhang L, Kokare C (2012) Production and stability studies of the biosurfactant isolated from marine Nocardiopsis sp. B4. Desalination 285:198-204

Kim HS, Yoon BD, Choung DH, Oh HM, Katsuragi T, Tani Y (1999) Characterization of a biosurfactant mannosylerythritol lipid produced from Candida sp. SY 16 Appl Microbiol Biotechnol 52:713-721

Kitamoto D, Ikegami T, Suzuki GT, Sasaki A, Takeyama Yl, Idemoto Y, Koura N, Yanagishita H (2001) Microbial conversion of $n$-alkanes into glycolipid biosurfactants, mannosylerythritol lipids, by Pseudozyma (Candida antarctica). Biotechnol Lett 23:1709-1714

Kosaric N (1992) Biosurfactants in industry. Pure Appl Chem 64:1731-1737

Langer O, Palme O, Wray V, Tokuda H, Lang S (2006) Production and modification of bioactive biosurfactants. Process Biochem 41:2138-2145

Makkar RS, Cameotra SS (2002) An update on the use of unconventional substrates for biosurfactant production and their new applications. App Microbiol Biotechnol 58:428-434

Makkar RS, Cameotra SS, Banat IM (2011) Advances in utilization of renewable substrates for biosurfactant production. AMB Express 1:1-19

Pacwa-Plociniczak M, Plaza GA, Piotrowska-Seget Z, Cameotra SS (2011) Enviornmental applications of biosurfactants: recent advances. Int J Mol Sci 12:633-654

Partovi M, Lotfabad TB, Roostaazad R, Bahmaei M, Tayyebi S (2013) Management of soybean oil refinery wastes through recycling them for producing biosurfactant using Pseudomonas aeruginosa MR01. World J Microbiol Biotechnol 29:1039-1047

Priya T, Usharani G (2009) Comparative study for biosurfactant production by using Bacillus subtilis and Pseudomonas aeruginosa. Bot Res Intl 2:284-287

Rufino RD, Sarubbo LA, Campos-Takaki GM (2007) Enhancement of stability of biosurfactant produced by Candida lipolytica using industrial residue as substrate. World J Microbiol Biotechnol 23:729-734

Sarachat T, Pornunthorntawee O, Chavadej S, Rujiravanit R (2010) Purification and concentration of rhamnolipid biosurfactant produced by Pseudomonas aeruginosa SP4 using foam fractionation. Bioresour Technol 101:324-330

Seghal Kiran G, Hema TA, Gandhimathia R, Selvina J, Anto Thomasa T, Rajeetha Ravji T, Natarajaseenivasan K (2009) Optimization and production of a biosurfactant from the sponge-associated marine fungus Aspergillus ustus MSF3. Colloids Surf B 73:250-256

Shavandi M, Mohebali G, Haddadi A, Shakarami H, Ashrafossadat N (2011) Emulsification potential of a newly isolated biosurfactant-producing bacterium, Rhodococcus sp. Strain TA6. Colloids Surf B 82:477-482

Soniyamby AR, Praveesh BV, Vimalin Hena J, Kavithakumari P, Lalitha S, Palaniswamy M (2011) Enhanced production of biosurfactant from isolated Pseudomonas sp growing on used edible oil. J Am Sci 7:50-52

Techaoei S, Lumyong S, Prathumpai W, Santiarwarn D, Leelapornpisid P (2011) Screening characterization and stability of biosurfactant produced by Pseudomonas aeruginosa SCMU106 isolated from soil in northern Thialand. Asian J Biol Sci 4:340-351

Thaniyavarn J, Chianguthai T, Sangvanich P, Roongsawang N, Washio K, Morikawa M, Thaniyavarn S (2008) Production of sophorolipid biosurfactant by Pichia anomala. Biosci Biotechnol Biochem 72:2061-2068

Thanomsub B, Watcharachaipong T, Chotelesersak K, Arunrattiyakorn P, Nitoda T (2004) Monoacyglycerols: glycolipid biosurfactants produced by a thermotolerant yeast, Candida ishiwadae. J Appl Microbiol 96:588-592

Thavasi R, Jayalakshmi S, Banat IM (2011) Application of biosurfactant produced from peanut oil cake by Lactobacillus delbrueckii in biodegradation of crude oil. Bioresour Technol 102:3366-3372

Wei YH, Chou CL, Chang JS (2005) Rhamnolipid production by indigenous Pseudomonas aeruginosa $\mathrm{J} 4$ originating from petrochemical wastewater. Biochem Eng J 27:146-154

Wu JY, Yeh KL, Lu WB, Lin CL, Chang JS (2008) Rhamnolipid production with indigenous Pseudomonas aeruginosa EM1 isolated from oil-contaminated site. Bioresour Technol 99:1157-1164

doi:10.1186/2191-0855-3-68

Cite this article as: Bhardwaj et al.: Utilization of oleo-chemical industry by-products for biosurfactant production. AMB Express 2013 3:68. 